JURNAL RISET MAHASISWA AKUNTANSI

http://ejournal.unikama.ac.id/index.php/jrma

JRMA, Volume 7, No 2, Oktober 2019

\title{
ANALISIS FAKTOR-FAKTOR YANG MEMPENGARUHI NILAI INFORMASI PELAPORAN KEUANGAN PEMERINTAH DAERAH
}

\author{
Rizky Rivaldo Peku Djawang \\ Email: rizkyrivaldopeku@.yahoo.co.id \\ Anwar Made \\ Ati Retnasari \\ Program Studi Akuntansi, Fakultas Ekonomika dan Bisnis Universitas Kanjuruhan \\ Malang
}

\begin{abstract}
ABSTRAK
Penelitian ini bertujuan untuk mengetahui pengaruh Pemahaman SAP, Penggunaan Teknologi Informasi, Pengawasan Internal, SDM, dan Komitmen Organisasi terhadap Nilai Informasi Laporan Keuangan baik secara parsial maupun simultan. Penelitian ini dilakukan di kabupaten Sumba Timur - Provinsi Nusa Tenggara Timur dengan menggunakan data primer kuesioner yang disebarkan ke pegawai DPKAD/DPPKD pemerintah Kota/Kabupaten Sumba Timur. Sampel yang digunakan berjumlah 35 orang yang terdiri dari pegawai yang bekerja atau menangani bagian akuntansi. Teknik analisis data yang digunakan dalam penelitian ini adalah analisis regresi linear berganda. Hasil penelitian menunjukkan bahwa Pemahaman SAP, Penggunaan Teknologi Informasi, Pengawasan Internal, Sumber Daya Manusia, dan Komitmen Organisasi berpengaruh secara simultan terhadap Nilai Informasi Laporan Keuangan dan secara parsial Pemahaman SAP, Penggunaan Teknologi Informasi, Sumber Daya Manusia berpengaruh positif dan siginifikan terhadap kinerja keuangan, tetapi Pengawasan Internal dan Komitmen organisasi tidak berpengaruh terhadap nilai informasi laporan keuangan di kabupaten Sumba Timur. Berdasarkan hasil tersebut dapat disimpulkan bahwa semakin besar Pemahaman SAP, Penggunaan Teknologi Informasi, Sumber Daya Manusia maka akan meningkatkan kualitas informasi laporan keuangan daerah, dan sebaliknya jika Pemahaman SAP, Penggunaan Teknologi Informasi, Sumber Daya Manusia menurun maka kualitas informasi laporan keuangan daerah juga akan menurun.
\end{abstract}

Kata kunci: Pemahaman SAP, Penggunaan Teknologi Informasi, Pengawasan Internal, Sumber Daya Manusia, dan Komitmen Organisasi dan Nilai Informasi Laporan Keuangan

\begin{abstract}
This study aims to determine the effect of SAP Understanding, Use of Information Technology, Internal Oversight, HR, and Organizational Commitment to the Value of Financial Statements, both partially and simultaneously. This research was conducted in East Sumba Regency - East Nusa Tenggara Province using primary questionnaire data distributed to DPKAD / DPPKD staff of the City / Regency of East Sumba. The sample used amounted to 35 people consisting of employees who work or handle the accounting department. The data analysis technique used in this study is multiple linear regression analysis. The results showed that SAP Understanding, Use of Information Technology, Internal Oversight, Human Resources, and Organizational Commitment simultaneously influence the Financial Statement Information Value and partially SAP Understanding, Use of Information Technology, Human Resources has a positive and significant
\end{abstract}


effect on financial performance, but Internal Control and Organizational Commitment do not affect the value of financial statement information in East Sumba district. Based on these results it can be concluded that the greater the SAP Understanding, Use of Information Technology, Human Resources will improve the quality of regional financial statement information, and vice versa if the Understanding of SAP, Use of Information Technology, Human Resources decreases the quality of regional financial statement information will also decrease

Keynotes: SAP Understanding, Use of Information Technology, Internal Oversight, HR, Organizational Commitment and Value of Financial Statements

\section{PENDAHULUAN}

Fenomena perkembangan pemerintahan di Indonesia saat ini adalah tuntutan akuntabilitas terhadap pemerintah baik di pusat maupun daerah. Pemerintah baik pusat maupun daerah, harus dapat menjadi subyek pemberi informasi dalam rangka pemenuhan hak-hak publik yaitu hak untuk tahu (right toknow), hak untuk diberi informasi (rightto be informed) dan hak untuk didengar aspirasinya (right to be heard and to be listened to) (Mardiasmo, 2009). Akuntabilitas keuangan adalah pemberian informasi atas aktivitas dalam menjaga keakuratan laporan keuangan kepada pihak-pihak yang berkepentingan. Laporan keuangan pemerintah dapat memenuhi kualitas yang dikehendaki haruslah memiliki keempat karakteristik kualitatif diatas sebagai prasyarat normatif yang perlu diwujudkan dalam informasi akuntansi sehingga dapat memenuhi tujuannya. Kualitas laporan keuangan akan meningkatkan kualitas informasi yang disajikan dalam laporan keuangan.

Salah satu faktor utama yang dapat meningkatkan kualitas informasi laporan keuangan adalah pengawasan intern. Pengawasan intern merupakan salah satu bagian dari kegiatan pengendalian intern yang berfungsi melakukan penilaian independen atas pelaksanaan tugas dan fungsi Instansi Pemerintah (Djalil, 2014). Semakin maraknya kasus korupsi yang terjadi pada Pemerintah Kabupaten belakangan ini menunjukan indikasi bahwa pengawasan internal belum berfungsi secara baik. Tahap pengawasan, seharusnya merupakan proses kegiatan yang ditujukan untuk menjamin agar pemerintahan berjalan secara ekonomis, efisien dan efektif sesuai dengan rencana dan ketentuan peraturan perundang-undangan. Hal tersebut belum sepenuhnya berfungsi sebagaimana mestinya.

Faktor lain yang mempengaruhi kualitas informasi laporan keuangan adalah pemahaman tentang peraturan. Peraturan yang dimaksud adalah pedoman yang harus dilakukan serta prosedur terkait dengan serangkaian strategi untuk mencapai tujuan dalam hal ini Peraturan Pemerintah Nomor 71 Tahun 2010 tentang SAP yang berbasis akrual. Penerapan akuntansi berbasis akrual diperlukan untuk menghasilkan pengukuran kinerja yang lebih baik, serta untuk memfasilitasi manajemen keuangan/aset yang lebih transparan dan akuntabel. Perubahan peraturan tentang akuntansi pemerintah dari basis kas ke basis akrual cukup kompleks sehingga diperlukan pemahaman yang utuh mengenai konsep akuntansi.

Hal lain yang mempengaruhi kualitas informasi laporan keuangan adalah penggunaan teknologi informasi. Teknologi informasi sudah menjadi pilihan utama dalam menciptakan sistem informasi suatu organisasi yang tangguh dan mampu melahirkan keunggulan kompetitif ditengah persaingan yang semakin ketat ini. Dengan kemajuan teknologi pada saat sekarang, instansi-instansi pemerintah sudah mulai meninggalkan sistem manual, beralih ke sistem komputer. Namun yang menjadi kendala penerapan teknologi informasi antara lain berkaitan dengan kondisi perangkat keras, perangkat lunak yang digunakan, pemutakhiran data, kondisi sumber daya manusia yang ada, dan keterbatasan dana. Kendala ini yang mungkin menjadi faktor penggunaan teknologi informasi di instansi pemerintah belum optimal. 
Selainitu hal lain yang mempengaruhi kualitas informasi laporan keuangan pemerintah daerah adalah komitmen organisasi. Komitmen dari Pemerintah Daerah dalam hal ini merupakan keinginan dari Satuan Kerja Perangkat Daerah (SKPD) untuk melakuan perubahan sesuai dengan adanya perubahan peraturan perundang-undangan. Adanya komitmen organisasi akan mempertahankan kepatuhan dalam penyajian laporan keuangan pemerintah yang reiable sesuai dengan standar akuntansi pemerintahan. Hal tersebut akan berdampak pada semakin baiknya kualitas dari informasi laporan keuangan. Pernyataan ini mendukung hasil penelitian Suwanda (2015), yaitu komitmen organisasi secara signifikan mempengaruhi Kualitas Laporan Keuangan Pemerintah Daerah.

Fenomena buruknya kualitas informasi laporan keuangan daerah memberikan peluang bagi adanya penyimpangan dan kekeliruan di bidang keuangan, terlihat dari banyaknya pejabat yang terjerat kasus hukum dan dapat menimbulkan kerugian negara/daerah. Administrasi keuangan yang buruk tersebut berlangsung terus menerus tentu saja rakyat akan menanggung akibatnya. Tata- kelola keuangan yang buruk menyebabkan ekonomi biaya tinggi: pelayanan kepada publik yang buruk, tingkat kerusakan fasilitas publik yang lebih cepat dan biaya transaksi yang tinggi. Fenomena ini menimbulkan kesenjangan antara harapan dan kenyataan. Harapan, dengan peningkatan kualitas SDM dan perbaikan peraturan dibidang manajemen keuangan daerah, menghasilkan informasi laporan keuangan yang berkualitas. Terjadinya kesenjangan menimbulkan pertanyaan tentang kualitas informasi laporan keuangan pemerintah daerah.

Hasil pemeriksaan BPK juga mengungkapkan 6.115 permasalah ketidak patuhan terhadap ketentuan peraturan perundang-undangan. Permasalahnan tersebut meliputi masalah yang mengakibatkan kerugian, potensi kerugian, dan kekurangan penerimaan (berdampak finansial) sebanyak 3.784 permasalahn senilai Rp2,08 triliun serta peyimpangan administrasi (tidak berdampak finansial) sebanyak 2.331 permasalahan. Permasalahan ketidak patuhan yang berdampak finansial meliputi permasalahn ketidak patuhan terhadap ketentuan peraturan perundang-undangan yang mengakibatkan kerugian sebanyak 2.525 permasalah senilai Rp1,13 triliun, potensi kerugian sebanyak 413 senilai Rp419,60 milliar, dan kekurangan penerimaan sebanyak 846 permasalahan senilai Rp537,72 milliar. Atas permasalahan ketidak patuhan tersebut, selama proses pemeriksaan entitas telah menindak lanjuti dangan melakukan penyetoran uang kas Negara/daerah atau penyerahan asset sebesar Rp 388,19 M.

Berdasarkan fenomena-fenomena tersebut, dapat disimpulkan bahwa laporan keuangan yang dihasilkan oleh pemerintah daerah masih belum memenuhi kriteria nilai informasi yang disyaratkan. Mengingat bahwa karakterisktik kualitatif merupakan unsur penting dalam Laporan Keuangan Pemerintah Daerah sebagai dasar pengambilan keputusan, maka peneliti tertarik untuk meneliti faktor apa saja yang dapat mempengaruhi keandalan dan ketepatan waktu pelaporan keuangan pemerintah daerah.

\section{Rumusan Masalah}

Apakah pemahaman standar akuntansi pemerintah, penggunaan teknologi informasi, pengawasan internal, kompetensi sumber daya manusia, komitmen organisasi secara simultan dan parsial berpengaruh terhadap kualitas informasi laporan keuangan pemerintah di Kabupaten Sumba Timur?

\section{Tujuan Penelitian}

Untuk menganalisis pengaruh standar akuntansi pemerintah, penggunaan teknologi informasi, pengawasan internal, kompetensi sumber daya manusia, komitmen organisasi secara simultan dan parsial berpengaruh terhadap kualitas informasi laporan keuangan di pemerintah di Kabupaten Sumba Timur secara simultan dan secara parsial. 


\section{TINJAUAN PUSTAKA}

\section{Kualitas Laporan Keuangan}

Laporan keuangan menurut PSAK No. 1 (2015:1) merupakan penyajian terstruktur dari posisi keuangan dan kinerja keuangan suatu entitas. Laporan ini menampilkan sejarah entitas yang dikuantifikasi dalam nilai moneter. Menurut Ikatan Akuntan Indonesia (IAI 2015:2) menjelasakan laporan keuangan sebagai berikut: “Laporan keuangan merupakan bagian dari proses pelaporan keuangan. Laporan keuangan yang lengkap biasanya meliputi neraca, laporan laba rugi, laporan perubahan posisi keuangan, catatan dan laporan lain serta materi penjelasan yang merupakan bagian integral dari laporan keuangan."

Berdasarkan Peraturan Pemerintah No. 71 Tahun 2010, komponen laporan keuangan terdiri dari: Laporan Realisasi Anggaran, Laporan Perubahan Saldo Anggaran Lebih, Neraca, Laporan Operasional, Laporan Arus Kas, Laporan Perubahan Ekuitas dan Catatan atas Laporan Keuangan. Laporan Keuangan memiliki karakteristik yaitu relevan, andal, dapart dibandingkan dan dapat dipahami.

\section{Penggunaan Teknologi Informasi}

Kemunculan Teknologi Informasi (TI) dapat meningkatkan kinerja dan memungkinkan berbagai kegiatan untuk dilaksanakan secara cepat, tepat dan akurat, sehingga akhirnya akan dapat meningkatkan produktivitas kerja. Teknologi informasi adalah gabungan antara teknologi komputer dan teknologi telekomunikasi (Kadir dan Triwahwuni, 2013:2). Teknologi komputer adalah teknologi yang berhubungan dengan komputer, termasuk peralatan-peralatan yang berhubungan dengan komputer seperti printer,pembaca sidik jari, bahkan CD ROM, sedangkan teknologi telekomunikasi adalah teknologi yang berhubungan dengan komunikasi jarak jauh (Kadir dan Triwahwuni, 2013:3). Menurut Darmawan (2014:16), secara sederhana teknologi informasi dapat dikatakan sebagai ilmu yang diperlukan untuk mengelola informasi agar informasi tersebut dapat dicari dengan mudah dan akurat. Isi dari ilmu tersebut merupakan teknikteknik dan prosedur untuk menyimpan informasi secara efisien dan efektif.

\section{Pengawasan Internal}

Peraturan Pemerintah Nomor 60 Tahun 2008 tentang Sistem Pengendalian Internal mendefinisikan Pengawasan Internal adalah seluruh proses kegiatan audit, reviu, evaluasi, pemantauan, dan kegiatan pengawasan lain terhadap penyelenggaraan tugas dan fungsi organisasi dalam rangka memberikan keyakinan yang memadai bahwa kegiatan telah dilaksanakan sesuai dengan tolok ukur yang telah ditetapkan secara efektif dan efisien untuk kepentingan pimpinan dalam mewujudkan tata kepemerintahan yang baik. Pengawasan internal merupakan salah satu bagian dari kegiatan pengendalian intern yang berfungsi melakukan penilaian independen atas pelaksanaan tugas dan fungsi Instansi Pemerintah.

\section{Kompetensi Sumber Daya Manusia}

Sumber daya manusia adalah orang-orang yang ada dalam organisasi yang memberikan sumbangan pemikiran dan melakukan berbagai jenis pekerjaan dalam mencapai tujuan organisasi. Menurut Zuliatri (2012), Kapasitas sumber daya manusia adalah kemampuan seseorang atau individu, suatu organisasi (kelembagaan), atau suatu sistem untuk melaksanakan fungsi-fungsi atau kewenangannya untuk mencapai tujuannya secara efektif dan efisien. Kapasitas harus dilihat sebagai kemampuan untuk mencapai kinerja, untuk menghasilkan keluaran-keluaran (outputs) dan hasil-hasil (outcomes).

\section{Komitmen Organisasi}

Pengelolaan sumber daya manusia oleh organisasi, perlu memperhatikan komitmen karyawannya. Komitmen karyawan yang tinggi akan sangat berpengaruh pada 
pencapaian tujuan organisasi. Organisasi akan lebih mudah untuk mencapai tujuan dan sasaran jika para karyawan mempunyai komitmen terhadap organisasi Komitmen Organisasi (Organization Commitment) adalah kemampuan dan kemauan untuk menyelaraskan perilaku pribadi dengan kebutuhan, prioritas dan sasaran organisasi (Wokas, 2011).

\section{Rumusan Hipotesis}

H1 : Pengaruh Standar Akuntansi Pemerintah, Penggunaan Teknologi Informasi, Pengawasan Internal, SDM, dan Komitmen Organisasi terhadap Nilai Informasi Laporan Keuangan

H2 : Pengaruh Standar Akuntansi Pemerintah Terhadap Nilai Informasi Laporan Keuangan

H3 : Pengaruh Penggunaan Teknologi Informasi Terhadap Nilai Informasi Laporan Keuangan

H4 : Pengaruh Pengawasan Internal Terhadap Nilai Informasi Laporan Keuangan

H5 : Pengaruh Kompetensi Sumber Daya Manusia Terhadap Nilai Informasi Laporan Keuangan

H6 : Pengaruh komitmen organisasi Terhadap Nilai Informasi Laporan Keuangan

\section{METODE PENELITIAN}

Penelitian ini dilakukan dengan menggunakan pendekatan kuantitatif. Populasi penelitian adalah semua pegawai Pemerintah Daerah SKPD Dinas Pendapatan dan Pengelolaan Keuangan Daerah (DPPKD) dan Dinas Pengelolaan Keuangan dan Aset Daerah (DPKAD) Kabupaten Sumba Timur. Teknik pengambilan sampel dalam penelitian ini menggunakan sampling jenuh yaitu sampel yang mewakili jumlah populasi. Jadi sampel dalam penelitian ini adalah seluruh populasi dengan Sampel dalam penelitian ini adalah pegawai Pemerintah Daerah SKPD Dinas Pendapatan dan Pengelolaan Keuangan Daerah (DPPKD) dan Dinas Pengelolaan Keuangan dan Aset Daerah (DPKAD) Kabupaten Sumba Timur. Data yang digunakan adalah data primer yang diperoleh dari penyebaran kuisioner.

Teknik analisis data yang digunakan adalah analisis linear berganda dengan uji asumsi klasik sebagai uji prasyaratnya. Menurut Yamin dan Kurniawan (2009) analisis regresi adalah sebuah pendekatan yang digunakan untuk mendefinisikan hubungan matematis antara variabel output/dependen $(\mathrm{Y})$ dengan satu atau beberapa variabel input/independen $(X)$. Hubungan linier ini secara sistematis digambarkan dalam rumus sebagai berikut:

$$
Y=\beta 0+\beta 1 X 1+\beta 2 X 2+\beta 3 X 3+e
$$

Keterangan:

$$
\begin{array}{ll}
\mathrm{Y} & =\text { kinerja keuangan daerah } \\
\beta 0 & =\text { Konstanta } \\
\beta 1-\beta 5 & =\text { Koefisien regresi dari setiap variabel independen. X1 } \\
& =\text { Standar Akuntansi Pemerintahan } \\
\mathrm{X} 2 & =\text { Penggunaan teknologi Informasi X3 } \\
& =\text { Pengawasan Internal } \\
\mathrm{X} 4 & =\text { Kompetensi SDM } \\
\mathrm{X} 5 & =\text { Komitmen Organisasi } \\
\mathrm{e} & =\text { Kesalahan pengganggu (error term) }
\end{array}
$$

Analisis regresi ada 3 analisis yang digunakan untuk pengujian hipotesis (Ghozali, 2011), yaitu: Uji F untuk mengetahui apakah variabel independen secara simultan berpangaruh signifkan terhadap variabel dependen, Uji $\mathrm{t}$ untuk mengetahui apakah variabel 
independen secara parsial berpangaruh signifkan terhadap variabel dependen dan uji koefisien determinasi disesuaikan (adjustedr2).

\section{HASIL PENELITIAN \\ Deskripsi Data}

Penelitian ini menggunakan data primer yang dikumpulkan melalui kuesioner dan dibagikan kepada responden penelitian. Responden dalam penelitian ini adalah pegawai yang melaksanakan fungsi akuntansi/tata usaha keuangan, yaitu Kepala Subbagian Keuangan, Akuntan (pembuku) dan Bendahara (penerimaan dan pengeluaran) yang bekerja pada SKPD di DPPKD dan DPKAD Kabupaten Sumba Timur. Peneliti membagikan kuesioner kepada responden sebanyak 40 kuesioner. Kuesioner yang kembali sejumlah 37 kuesioner, dan kuesioner yang diolah untuk analisis data sebanyak 35 kuesioner, sedangkan 2 kuesioner lainnya merupakan data yang bersifat outlier sehingga peneliti tidak menggunakan data-data tersebut agar tidak menimbulkan bias pada hasil penelitian.

\section{Hasil Analisis Data}

\section{Hasil Pengujian Asumsi Klasik}

1. Hasil Uji Asumsi Klasik Autokorelasi

Hasil uji asumsi klasik autokorelasi menggunakan pendekatan Durbin Watson. Hasilnya menunjukkan bahwa nilai Durbin Watson 1,696 terletak di antara 1,55-2,46 (Sugiyono, 2012). Hasil ini menunjukkan tidak terjadi autokorelasi.

2. Hasil Uji Asumsi Klasik Multikolinieritas

Tabel 1

Hasil Uji Asumsi Klasik Multikolinieritas

Coefficients ${ }^{\mathrm{a}}$

\begin{tabular}{|c|c|c|c|c|c|c|c|}
\hline \multirow[b]{2}{*}{ Model } & \multicolumn{2}{|c|}{$\begin{array}{l}\text { Unstandardized } \\
\text { Coefficients }\end{array}$} & \multirow{2}{*}{$\begin{array}{c}\text { Standardized } \\
\text { Coefficients } \\
\text { Beta }\end{array}$} & \multirow[b]{2}{*}{$\mathrm{t}$} & \multirow[b]{2}{*}{ Sig. } & \multicolumn{2}{|c|}{$\begin{array}{c}\text { Collinearity } \\
\text { Statistics }\end{array}$} \\
\hline & B & Std. Error & & & & $\begin{array}{c}\text { Toleranc } \\
\mathrm{e}\end{array}$ & VIF \\
\hline 1 (Constant) & -8.829 & 7.589 & & -1.163 & .254 & & \\
\hline $\mathrm{X} 1$ & .646 & .187 & .536 & 3.460 & .002 & .585 & 1.711 \\
\hline $\mathrm{X} 2$ & .386 & .130 & .421 & 2.982 & .006 & .704 & 1.420 \\
\hline $\mathrm{X} 3$ & -.377 & 2.785 & -.401 & -.135 & .893 & .002 & 6.258 \\
\hline $\mathrm{X} 4$ & .586 & .191 & .430 & 3.069 & .005 & .713 & 1.403 \\
\hline $\mathrm{X} 5$ & .315 & 2.738 & .339 & .115 & .909 & .002 & 6.195 \\
\hline
\end{tabular}

a. Dependent Variable: $\mathrm{Y}$

Sumber: data sekunder diolah peneliti tahun 2019.

Pada tabel tersebut telihat bahwa nilai VIF setiap variabel dibawah 10. Hal ini menunjukkan bahwa tidak terjadi multikolinieritas. 
3. Hasil Uji Asumsi Klasik Heteroskedastisitas

Seatterplot

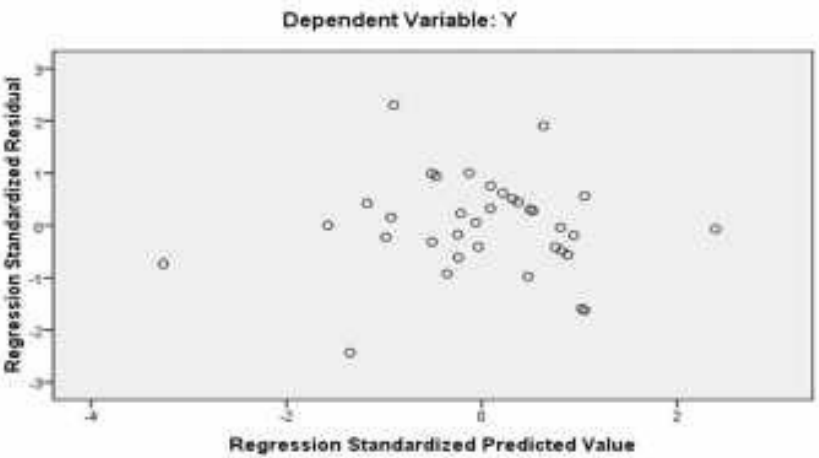

Sumber: data sekunder diolah peneliti tahun 2019.

\section{Gambar 1 Grafik}

Plot (Scatter Plot)

Dari gambar grafik plot tersebut menunjukkan tidak beraturan atau tidak membentuk suatu pola atau gambar tertentu dengan demikian tidak terjadi heteroskedastisitas.

4. Hasil Uji Asumsi Klasik Normalitas

Tabel 2

Hasil Uji Asumsi Klasik Normalitas

One-Sample Kolmogorov-Smirnov Test

\begin{tabular}{|c|c|c|c|c|c|c|c|}
\hline & $\mathrm{x} 1$ & $x 2$ & $\mathrm{x} 3$ & $\mathrm{x} 4$ & $\mathrm{x} 5$ & $\mathrm{y}$ \\
\hline \multicolumn{2}{|l|}{$\mathrm{N}$} & 35 & 35 & 35 & 35 & 35 & 35 \\
\hline \multirow[t]{2}{*}{ Normal Parameters ${ }^{\mathrm{a}}$} & Mean & 29.06 & 33.83 & 35.63 & 29.40 & 35.60 & 38.03 \\
\hline & Std. Deviation & 2.754 & 3.618 & 3.532 & 2.440 & 3.574 & 3.321 \\
\hline \multirow{3}{*}{$\begin{array}{l}\text { Most Extreme } \\
\text { Differences }\end{array}$} & Absolute & .120 & .141 & .172 & .197 & .176 & .162 \\
\hline & Positive & .057 & .096 & .092 & .115 & .091 & .162 \\
\hline & Negative & -.120 & -.141 & -.172 & -.197 & -.176 & -.158 \\
\hline \multicolumn{2}{|c|}{ Kolmogorov-Smirnov Z } & .712 & .836 & 1.019 & 1.166 & 1.042 & .959 \\
\hline \multicolumn{2}{|l|}{ Asymp. Sig. (2-tailed) } & .692 & .487 & .250 & .132 & .227 & .317 \\
\hline
\end{tabular}

a. Test distribution is Normal.

Sumber: data sekunder diolah peneliti tahun 2018

Pada tabel tersebut menunjukkan bahwa nilai signifikan variabel X1, X2, X3, X4, X5, danY lebih besar dari 0,05, jadi menunjukkan bahwa data tersebut berdistribusi normal.

\section{Hasil Analisis Regresi Linear Berganda}

\section{Uji F}

Dari Tabel 3 berikut ini dapat dilihat bahwa nilai sig. F lebih kecil dari 0,05 artinya secara simultan variabel $\mathrm{X}$ berpengaruh terhadap variabel $\mathrm{Y}$. 


\section{Tabel 3}

\section{Uji F ANOVA ${ }^{b}$}

\begin{tabular}{|l|r|r|r|r|r|}
\hline Model & Sum of Squares & df & Mean Square & F & Sig. \\
\hline 1 Regression & 222.508 & 5 & 44.502 & 8.465 & $.000^{a}$ \\
Residual & 152.463 & 29 & 5.257 & & \\
Total & 374.971 & 34 & & & \\
\hline
\end{tabular}

a. Predictors: (Constant), X5, X2, X4, X1, X3

b. Dependent Variable: Y

Sumber: data sekunder diolah peneliti tahun 2018.

Dari Tabel 4.7 diatas dapat dilihat bahwa nilai sig. F lebih kecil dari 0,05 artinya secara simultan variabel $\mathrm{X}$ berpengaruh terhadap variabel $\mathrm{Y}$.

\section{Uji T}

Hasil uji T dapat diihat dalam tabel sebelumnya yaitu Tabel 1. Dari tabel tersebut dapat dilihat bahwa nilai sig. variabel $X<0,05$ jadi dapat disimpulkan bahwa variabel $\mathrm{X}$ berpengaruh secara parsial terhadap variabel $\mathrm{Y}$.

\section{Model Persamaan Regresi}

$\mathrm{Y}=-8,829+0,646 \mathrm{X} 1+0,386 \mathrm{X} 2-0,377 \mathrm{X} 3+0,586 \mathrm{X} 4-0,315 \mathrm{X} 5$

Model persamaan regresi berganda di atas menunjukkan:

a. $\quad \mathrm{Y}=$ Nilai konstanta sebesar $-8,829$, artinya apabila tidak ada variabel independen, maka nilai informasi laporan keuangan sebesar 47,380

b. X1 sebesar 0,646 menunjukkan bahwa setiap kenaikan Pemahaman Standar Akuntansi Pemerintahan sebesar 1 satuan akan diikuti kenaikan Nilai Informasi Laporan Keuangan sebesar 0,646 dengan asumsi variabel lain tetap.

c. X2 sebesar 0,386 menunjukkan bahwa setiap kenaikan Penggunaan Teknologi Informasi sebesar 1 satuan akan diikuti kenaikan Nilai Informasi Laporan Keuangan sebesar 0,386 dengan asumsi variabel lain tetap.

d. X3 sebesar - 0,377 menunjukkan bahwa setiap kenaikan Pengawasan Internal sebesar 1 satuan akan diikuti penurunan Nilai Informasi Laporan Keuangan sebesar - 0,377 dengan asumsi variabel lain tetap.

e. X4 sebesar 0,586 menunjukkan bahwa setiap kenaikan SDM sebesar 1 satuan akan diikuti kenaikan Nilai Informasi Laporan Keuangan sebesar 0,586 dengan asumsi variabel lain tetap.

f. X2 sebesar 0,315. Koefisien regresi variabel Komitmen Organisasi bertanda positif yaitu 0,315 dan nilai signifikansinya 0,909 melebihi standar nilai signifikan 0,05. Hal ini berarti bahwa variabel Komitmen Organisasi tidak berpengaruh terhadap Nilai Informasi Laporan Keuangan.

\section{R Square}

Nilai R Square ini mencerminkan seberapa besar variasi dari variabel terikat $Y$ dapat diterangkan oleh variabel bebas $X$. Hasil penelitian menunjukkan bahwa nilai variabel $Y$ dapat diterangkan sebesar 59,3\% oleh variabe $X$ dan sisanya 40,7\% diterangkan oleh variabel lain yang tidak diteliti dalam penelitian ini.

\section{Pembahasan Hipotesis}

Pengaruh Pemahaman SAP, Penggunaan Teknologi Informasi, Pengawasan Internal, SDM, dan Komitmen Organisasi terhadap Nilai Informasi Laporan Keuangan 
Hasil penelitian menunjukkan bahwa nilai signifikan secara simultan (ujif) variabel Pemahaman SAP, Penggunaan Teknologi Informasi, Pengawasan Internal, SDM, dan Komitmen Organisasi sebesar 0,000 (lebih kecil dari alpa 0.05). Hasil uji-f tersebut menunjukkan bahwa variabel Pemahaman SAP, Penggunaan Teknologi Informasi, Pengawasan Internal, SDM, dan Komitmen Organisasi secara bersama-sama berpengaruh terhadap Nilai Informasi Laporan Keuangan pemerintah daerah. Hasil penelitian ini didukung oleh penelitian Muhamad Rifandi (2018) yang mengatakan bahwa teknologi informasi dan pengawasan keuangan berpengaruh terhadap nilai informasi laporan keuangan pemerintah daerah dan penelitian dari Andika Yulianto yang mengatakan bahwa kompetensi sumber daya manusia, komitmen organisasi, pemanfaatan teknologi informasi, dan penerapan sistem pengendalian intern berpengaruh terhadap nilai informasi laporan keuangan dengan penerapan SAP berbasis akrual.

\section{Pengaruh Pemahaman SAP terhadap Nilai Informasi Laporan Keuangan}

Hasil penelitian menunjukkan bahwa nilai signifikan secara parsial (uji-t) variabel Pemahaman SAP yaitu sebesar 0,002 (lebih kecil dari alpa 0.05) dan nilai koefisien yang sudah distandarisasi bertanda positif sebesar 0,646. Jika variabel Pemahaman SAP dinaikkan satu satuan, maka Nilai Informasi Laporan Keuangan akan meningkat sebesar 0,646. Hal ini menunjukkan bahwa variabel Pemahaman SAP secara parsial berpengaruh terhadap Nilai Informasi Laporan Keuangan daerah di kabupaten Sumba Timur. Hasil penelitian ini juga didukung oleh penelitian dari Suwanda (2015) yang mengatakan bahwa SAP secara signifikan mempengaruhi Kualitas Laporan Keuangan Pemerintah Daerah. Semakin tinggi pemahaman tentang SAP maka akan semakin baik nilai laporan informasi keuangan.

Pemahaman SAP secara parsial berpengaruh terhadap nilai informasi laporan keuangan dai kabupaten Sumba Timur karena dalam pembuatan laporan keuangan dibutuhkan pemahaman tentang SAP secara mendalam. SAP itu sendiri merupakan standar yang ditetapkan sebagai pedoman dalam pembuatan laporan keuangan sehingga nilai informasi dari laporan keuangan tersebut benar-benar seusai dengan unsur-unsur laporan keuangan yaitu relevan, andal, dapat dibandingkan dan dapat dipahami. Jadi untuk membuat laporan keuangan yang memiliki nilai informasi yang sesuai dengan unsur-unsur tersebut maka dibutuhkan pemahaman yang baik tentang Standar Akuntansi Pemerintah.

\section{Pengaruh Penggunaan Teknologi Informasi terhadap Nilai Informasi Laporan Keuangan}

Hasil penelitian menunjukkan bahwa nilai signifikan secara parsial (uji-t) variabel Penggunaan Teknologi Informasi yaitu sebesar 0,006 (lebih kecil dari alpa 0.05) dan nilai koefisien yang sudah distandarisasi bertanda positif sebesar 0,386. Jika variabel Penggunaan Teknologi Informasi dinaikkan satu satuan, maka Nilai Informasi Laporan Keuangan akan meningkat sebesar 0,386. Hal ini menunjukkan bahwa variabel Penggunaan Teknologi Informasi secara parsial berpengaruh terhadap Nilai Informasi Laporan Keuangan daerah di kabupaten Sumba Timur. Hasil penelitian ini juga didukung oleh penelitian dari Rifandi (2018) dan Indrawati (2013) yang mengatakan bahwa pemanfaatan teknologi informasi memiliki pengaruh yang signifikan terhadap nilai informasi laporan keuangan. Semakin baik pemanfaatan teknologi informasi maka kualitas nilai informasi laporan keuangan akan semakin baik.

Berdasarkan hasil pengolahan data dari kuesioner yang disebarkan di DPKAD/DPPKD pemerintah Kota/Kabupaten Sumba Timur, rata-rata jawabannya adalah setuju dengan pernyataan yang terdapat dalam kuesioner. Hasil ini menunjukkan bahwa 
pemanfaatan teknologi informasi menentukan kualitas nilai informasi laporan keuangan daerah di kabupaten Sumba Timur. Pemerintah kabupaten Sumba Timur juga telah mampu memanfaatkan teknologi informasi untuk mendukung penyajian laporan keuangan sehingga nilai informasi dari laporan keuangan dapat ditingkatkan dan memenuhi karakteristik kualitatif.

Pengaruh Pengawasan Internal terhadap Nilai Informasi Laporan Keuangan Hasil penelitian menunjukkan bahwa nilai signifikan secara parsial (uji-t) variabel Pengawasan Internal yaitu sebesar 0,893 (lebih besar dari alpa 0.05) dan nilai koefisien yang sudah distandarisasi bertanda negatif sebesar -0,377. Hal ini menunjukkan bahwa variabel pengawasan Internal tidak berpengaruh terhadap Nilai Informasi Laporan Keuangan daerah di kabupaten Sumba Timur. Hasil penelitian ini juga didukung oleh penelitian dari Brendhi Septo Nugroho (2018) yang mengatakan bahwa pengawasan internal tidak berpengaruih terhadap nilai informasi laporan keuangan, akan tetapi hasil penelitian ini tidak sejalan dengan penelitian dari Suwanda (2015) yang menyatakan bahwa implementasi sistem pengendalian internal secara signifikan mempengaruhi kualitas laporan keuangan pemerintah daerah

Hasil penelitian ini menunjukan bahwa tidak adanya pengaruh pengawasan internal terhadap nilai informasi laporan keuangan pemerintah daerah di sebabkan karena didalam pelaksanan pengawasan internal secara lengkap dan menyeluruh terhadap sistem akuntansi tidak mempengaruhi penyusunan laporan keuangan. Pengawasan Internal secara lengkap dan menyeluruh belum sepenuhnya mengurangi pelanggaran terhadap sistem dan prosedur akuntansi. Di dalam pelaksanaan pengawasan internal secara terus menerus setiap hasil temuan belum tentu dapat mendeteksi kecurangan dalam proses akuntansi, sehingga menyebabkan bukti audit yang diperoleh dari data akuntansi tersebut menjadi tidak relevan. Dengan demikian pengawasan internal tidak mempengaruhi kualitas informasi laporan keuangan. Pengawasan internal yang tidak berpengaruh terhadap nilai informasi laporan keuangan daerah di kabupaten Sumba Timur juga bisa terjadi karena pengawasan internal yang dilakukan DPKAD/ DPPKD pemerintah Kota/Kabupaten Sumba Timur belum maksimal dilakukan sehingga terjadi kelemahan dalam pengawasan yang dapat menyebabkan kebocoran dan ketidakpatuhan terhadap peraturan perundang-undangan.

\section{Pengaruh Sumber Daya Manusia terhadap Nilai Informasi Laporan Keuangan}

Hasil penelitian menunjukkan bahwa nilai signifikan secara parsial (uji-t) variabel Sumber Daya Manusia yaitu sebesar 0,005 (lebih kecil dari alpa 0.05) dan nilai koefisien yang sudah distandarisasi bertanda positif sebesar 0,586. Jika variabel Sumber Daya Manusia dinaikkan satu satuan, maka Nilai Informasi Laporan Keuangan akan meningkat sebesar 0,586. Hal ini menunjukkan bahwa variabel Sumber Daya Manusia secara parsial berpengaruh terhadap Nilai Informasi Laporan Keuangan daerah di kabupaten Sumba Timur. Hasil penelitian ini tidak mendukung penelitian dari Suwanda (2015) yang mengatakan bahwa Sumber Daya Manusia tidak berpengaruh terhadap kualitas informasi laporan keuangan tetapi hasil penelitian ini didukung oleh penelitian dari Choirunisah (2008) yang menyatakan bahwa kemampuan sumber daya manusia berpengaruh signifikan terhadap kualitas informasi keuangan. Hal ini berarti dengan kompetensi sumber daya manusia yang baik, maka kualitas informasi laporan keuangan pemerintah daerah kabupaten Sumba Timur akan semakin membaik. Semakin tinggi tingkat sumber daya manusia maka akan semakin tinggi tingkat kualitas nilai informasi laporan keuangan pemerintah daerah kabupaten Sumba Timur. Begitu pula sebaliknya semakin rendah tingkat sumber daya manusia maka akan semakin rendah tingkat kualitas nilai informasi 
laporan keuangan pemerintah daerah kabupaten Sumba Timur.

\section{Pengaruh Komitmen Organisasi terhadap Nilai Informasi Laporan Keuangan}

Hasil penelitian menunjukkan bahwa nilai signifikan secara parsial (uji-t) variabel Komitmen Organisasi yaitu sebesar 0,909 (lebih besar dari alpa 0.05) dan nilai koefisien yang sudah distandarisasi bertanda positif sebesar 0,315. Hal ini berarti bahwa variabel Komitmen Organisasi secara parsial tidak berpengaruh terhadap Nilai Informasi Laporan Keuangan. Hasil penelitian ini tidak sejalan dengan penelitian yang dilakukan Suwanda (2015) yang menyatakan bahwa komitmen organisasi secara signifikan mempengaruhi kualitas laporan keuangan pemerintah daerah, akan tetapi hasil penelitian ini sejalan dengan peneiltian dari Andika Yulianto (2018) yang mengatakan bahwa komitmen organisasi tidak berpengaruh terhadap nilai informasi laporan keuangan daerah.

Lemahnya komitmen organisasi di Kabupaten Sumba Timur ini juga dikarenakan oleh adanya hubungan keluarga di dalam organisasi tersebut. Adanya hubungan keluarga ini menyebabkan para pegawai disana kurang memperhatikan factor-faktor komitmen organisasi seperti umur, pengalaman kerja, masa kerja, dan tingkat pendidikan karena bagi para pegawai sudah mengandalkan prinsip orang dalam. Jika ada hubungan keluarga maka bisa bekerja. Jadi dapat disimpulkan bahwa meskipun komitmen organisasi dari para pegawai di DPKAD/ DPPKD pemerintah Kota/Kabupaten Sumba Timur tergolong rendah ataupun tinggi, tidak akan mempengaruhi kualitas nilai informasi laporan keuangan tersebut. Karena pada dasarnya untuk menghasilkan laporan keuangan yang berkualitas dibutuhkan standar akuntansi yang baik, sumber daya manusia yang mumpuni dan juga didukung dengan teknologi informasi.

\section{Kesimpulan}

Berdasarkan pengujian dan penjelasan yang telah dilakukan pada bab sebelumnya, dapat disimpulkan bahwa: Pemahaman SAP, Penggunaan Teknologi Informasi, Pengawasan Internal, SDM, dan Komitmen Organisasi secara simultan atau secara bersama-sama berpengaruh terhadap Nilai Informasi Laporan Keuangan di kabupaten Sumba Timur. Akan tetapi secara parsial hanya variabel Pemahaman SAP, Penggunaan Teknologi Informasi, dan Sumber Daya Manusia yang berpengaruh terhadap Nilai Informasi Laporan Keuangan di kabupaten Sumba Timur, sedangkan variabel pengawasan internal dan variabel komitmen organisasi tidak berpengaruh terhadap Nilai Informasi Laporan Keuangan di kabupaten Sumba Timur. Variabel Pemahaman SAP, Penggunaan Teknologi Informasi, dan Sumber Daya Manusia memiliki pengaruh positif dan signifikan terhadap nilai informasi laporan keuangan daerah. Hal ini berarti jika Pemahaman SAP, Penggunaan Teknologi Informasi, dan Sumber Daya Manusia meningkat maka nilai informasi laporan keuangan juga akan semakin baik dan berguna bagi para penggunanya, begitupun sebaliknya, jika Pemahaman SAP, Penggunaan Teknologi Informasi, dan Sumber Daya Manusia menurun maka nilai informasi laporan keuangan daerah akan semakin memburuk.

\section{DAFTAR PUSTAKA}

Darmawan, Deni. 2012. Pendidikan Teknologi Informasi Dan Komunikasi. Bandung: PT. Remaja Rosdakarya.

Djalil, Rizal. 2014. Akuntabilitas Keuangan Daerah Implementasi Pasca Reformasi. Jakarta: RMBOOKS.

Ikatan Akuntan Indonesia. 2015. Standar Akuntansi Keuangan, PSAK No. 1: Penyajian Laporan Keuangan. Jakarta: Salemba Empat. 
Rizky Rivaldo Peku Djawang, Analisis Faktor-Faktor Yang Mempengaruhi Nilai Informasi Pelaporan

Keuangan Pemerintah Daerah

Kadir, A. dan T. Ch. Triwahyuni. 2013. Pengantar Teknologi Informasi Edisi Revisi. Yogyakarta: CV. Andi Offset.

Mardiasmo. 2009. Akuntansi Sektor Publik. Andi: Yogyakarta.

Peraturan Pemerintah Nomor 71 Tahun 2010 tentang Standar Akuntansi Pemerintahan.

Republik Indonesia. 2014. Nomor 23 Tahun 2014 Tentang Pemerintah Daerah. Jakarta

Sugiyono (2011) Metode Penelitian Kualitatif, Kuantitatif dan R\&D. Bandung: ALFABETA.

Sugiyono (2012) Memahami Penelitian Kualitatif. Bandung: ALFABETA. Suwanda, Dadang. 2015. " Factors Affecting Quality of Local Government Financial Statements to Get Unqualified Opinion (WTP) of Audit Board of the Republic of Indonesia (BPK) ". Faculty of Economics and Business, University of Padjajaran Bandung.

Zuliarti, 2012. "Pengaruh Kapasitas Sumber Daya Manusia,Pemanfaatan Teknologi Informasi, Dan Pengendalian Intern Akuntansi Terhadap Nilai Informasi Pelaporan Keuangan Pemerintah Daerah". Fakultas Ekonomi Universitas Muria Kudus.

PP Nomor 24 Tahun 2005 tentang Standar Akuntansi Pemerintahan 